\section{A spatial-temporal analysis of civil war: The case of Nepal}

\section{Shikha Silwal}

$\mathrm{W}$

ar occurs along spatial and temporal dimensions. However, each tends to be studied separately and independently of the other, and the relationship between them remains mostly unexplored and unexplained. Moreover, the spatial spread of war is considered, if at all, primarily across international boundaries, not within a country. As a result, studies cannot fully quantify the intensity of war over time and also understand the factors that contribute to its spatial dimension. And yet, we surely need to learn why, in war, certain physical areas are engulfed in violence whereas others remain relatively unaffected by it. ${ }^{1}$

This leads to important sub-questions. How can one integrate space and time to study the characteristics of war? Can one explain war as a dynamic phenomenon with only local drivers, such as poverty and low literacy rates, behind its upsurge? If violence is a spatial-temporal process, is the spread completely spatial like the spread of a disease? And once an area is engaged in war, how does the violence evolve in time?

To address these types of questions, data with sufficient variation in the temporal and geographical spread of war are required. A civil war case that fits the requirements is that of in Nepal in the 1990s and 2000s. Within seven years of its initiation, in 1996, what initially were small-scale anti-government protests grew ferocious enough to be classified as war and had spread throughout the country. ${ }^{2}$ Three major studies have appeared on the Maoist insurgency in Nepal. One analyzes the pattern of the exchange of violence between government and insurgents, and how that pattern varies with the socioeconomic conditions of a district. The two others analyze factors contributing to the escalation of violence. But, unlike the study in this article, none exploit the temporal variation in violence nor do they account for its geographic spread. ${ }^{3}$

Like the spread of an infectious disease, war can be broken down into two stages: an infection stage and an escalation stage. In the infection stage, an area becomes engaged in civil war in a certain location at a certain point in time. In the escalation stage, war spreads in time. The novelty of this article lies not in its qualitative finding but in its quantitative demonstration: First, the geographically closer an unaffected area lies to an affected area, the more quickly it gets drawn into the violence and, second, the earlier the exposure to violence, the higher its eventual intensity. Importantly, local socioeconomic conditions, such as poverty, literacy rate, and forest density do not explain contagion or escalation.
Data

Many local factors may influence the manner in which violence unfolds. For example, poverty and literacy rates are thought to cause grievances, which then can lead to outbursts of violence. As such, the percentage of the population of a district living below the national poverty line before the war is used to measure relative poverty in a district. This data comes from the Nepal Living Standard Survey (1995-1996). Poverty, however, can be endogenous to the spread of war as higher levels of poverty can both be a result and a cause of conflict. To control for this statistically, one may use rainfall as an exogenous source of variation in income, certainly for economies such as Nepal's which are heavily reliant on agriculture (it is Nepal's largest economic sector). Thus, annual precipitation is a reasonable indicator of exogenous shocks to income and helps one to check on the robustness of the poverty measure. $^{4}$

While grievance can motivate citizens to revolt against their government, the literature has suggested that rebellious activities can grow simply because such opportunity exists. Dense forest, rugged terrain, and lack of roads are thought to create a suitable environment for rebels to thrive as those areas are less accessible to government. Since Nepal is a mountainous country, there is a possibility that geography favored the rebels by providing a safe haven from government forces. Hence, I use the percentage of a district area covered by forest (forest density), length of roads per district area (road density), average elevation, and population per district area (population density) as measures of opportunities for rebellious activities. But road density and elevation are highly correlated, and so only road density is used in the main analysis. (Results are not sensitive to using either of these two variables.) All of these socioeconomic and geography indicators are measured at the district level in the prewar period (before 1996). ${ }^{5}$

Studies that analyze the spatial spillover of war view simple geographic proximity as a key driver of war spread: War spreads not because the socioeconomic condition of an area is suitable to breed insurgents, but because it is close to an area already affected by war. Distance from areas from where war began is used as a measure of proximity. Studies also use distance from a country's capital to analyze rebel activity. But for this article, distance from the capital, Kathmandu, is not particularly suitable since it would measure mere clustering of rebellious activities nearer or further away 
from the capital. But clustering is a function of rebel motivation as much as it may be a function of distance from the capital. Further, if our interest is in understanding the spread of war, the diffusion from the starting point of war should be the reference point, and this may or may not be the capital. ${ }^{6}$

Besides these drivers of violence, one expects that politics should also have an influence on the prevalence of armed struggle. Some scholars argue that more important than the geography or topology of a place is its strategic value, e.g., its population base or size. While studies tend to focus on mere population density as a possible advantage (or disadvantage) of a location, deeper knowledge is required to fully grasp the strategic advantage a population may provide. I use the share of votes the Communist Party received in the 1994 House of Representatives election as an indicator to think of an area as a "communist stronghold". This election was the last election held immediately prior to the insurgency and it captures local support for communist ideology. Data are obtained from the Election Commission and are a proxy for consolidation of communist supporters within a district. ${ }^{7}$

Another way of identifying the strategic advantage a population may offer is to look at its ethnic composition. Some ethnic groups are known to be militarily skilled and inclined (they are "military in nature"). The Magars for example were soldiers in the King's army who fought to unite the country (1765-1768). Although forming part of the ruling elite in the initial post-unification years, nevertheless they became marginalized in time and now view themselves as neglected by the government. Scholars ague that a history of neglect felt by this group, and their militant nature, gave Maoists much-needed support. It has also been pointed out that these ex-army members provided arms and military training to the Maoists. I use Census data for 1990 to calculate the share of a population that belongs to an ethnic group thought to be militant in nature. This is labeled as "ethnicity". Together with "communist stronghold", the two variables are indicative of local politics and are hypothesized to capture the strategic importance of a location. ${ }^{8}$

Finally, the levels of violence for the entire duration of the war, from 1996 to 2006, were obtained from the Informal Sector Service Center (INSEC). The Center monitors yearly levels of human rights violations, by government or by insurgents. As only killing data is available throughout the period, I use them weighted by district population in 1990 to code for the intensity of the violence. After 2001, violence escalated when the government began to engage in counter-insurgency operations. Also, several rounds of futile peace talks and cease-fires were held after 2001. For these reasons and because after 2001 the entire country was affected by war, which necessarily reduces variation in war onset to zero, I use the data from 1996-2001 only.

Descriptive statistics are presented in Table 1 and broken down by proximity in Table 2. Districts within 50 kilometers of war-affected areas are classified as "nearby" districts, and districts more than 100 kilometers away are "far away" districts, and the remainder are in-between. As Table 2 shows, the districts are rather comparable in terms of their socioeconomic character except for the year of conflict onset and the
Table 1: Descriptive statistics

$\begin{array}{llllll}\text { Variable } & \text { Obs. } & \text { Mean } & \text { Std } & \text { Min. } & \text { Max. } \\ \text { \% below poverty line } & 75 & 0.382 & 0.125 & 0.044 & 0.603 \\ \text { Literacy rate } & 75 & 0.380 & 0.110 & 0.196 & 0.701 \\ \text { Population density } & 75 & 204.6 & 267.2 & 2.388 & 1709.7 \\ \text { Forest density } & 75 & 0.398 & 0.189 & 0.017 & 0.983 \\ \text { Road density } & 75 & 0.113 & 0.210 & 0.000 & 1.329 \\ \text { Communist stronghold }(a) & 75 & 0.317 & 0.150 & 0.000 & 0.794 \\ \text { Ethnicity }(b) & 75 & 0.243 & 0.217 & 0.002 & 0.979 \\ \text { Cumulative deaths per } & & & & & \\ \text { 10,000 population in 2001 } & 75 & 1.761 & 3.949 & 0.000 & 20.38\end{array}$

Table 2: Descriptive statistics by proximity

$\begin{array}{llll}\text { Variable } & 0-50 \mathrm{~km} & \begin{array}{l}51-100 \mathrm{~km} \\ \text { Mean }(\mathrm{std})\end{array} & \begin{array}{l}>100 \mathrm{~km} \\ \text { Mean }(\mathrm{std})\end{array} \\ \text { Cumulative deaths per } & & & \\ 10,000 \text { population } & 3.853 & 1.093 & 0.272 \\ & (5.714) & (2.729) & (0.436) \\ \text { Year of conflict onset }(c) & 1.840 & 3.240 & 4.478 \\ & (1.700) & (1.268) & (1.122) \\ \text { Distance } & 31.436 & 76.271 & 141.046 \\ & (20.358) & (13.109) & (32.122) \\ \text { Poverty } & 0.388 & 0.392 & 0.377 \\ & (0.133) & (0.132) & (0.111) \\ \text { Literacy rate } & 0.343 & 0.381 & 0.413 \\ & (0.111) & (0.116) & (0.096) \\ \text { Population density } & 2.598 & 1.851 & 1.835 \\ & (4.173) & (1.571) & (1.235) \\ \text { Forest density } & 0.423 & 0.427 & 0.371 \\ & (0.223) & (0.126) & (0.188) \\ \text { Road density } & 0.150 & 0.105 & 0.091 \\ & (0.324) & (0.147) & (0.082) \\ \text { Communist stronghold }(a) & 0.257 & 0.362 & 0.355 \\ & (0.143) & (0.147) & (0.128) \\ \text { Ethnicity }(b) & 0.259 & 0.237 & 0.196 \\ \text { Observations }(\mathrm{N}) & (0.175) & (0.249) & (0.198) \\ & 25 & 27 & 23\end{array}$

Notes: $\mathrm{Std}=$ Standard deviation. ( $a$ ) Communist stronghold is the percentage of votes received by the Communist Party in the 1994 House of Representatives election. (b) Ethnicity is the share of ethnic groups thought to be militant in nature: Magar, Rai, Tamang, Limbu, and Gurung. (c) Year of conflict onset: 1996=0, 1997=1, etc. 


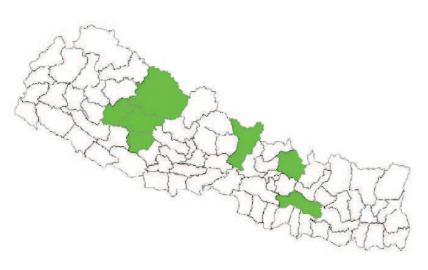

Figure 1: Districts affected in 1996

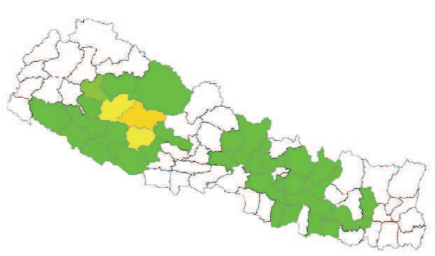

Figure 3: Districts affected in 1998

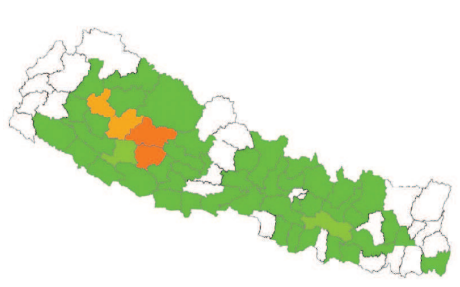

Figure 5: Districts affected in 2000

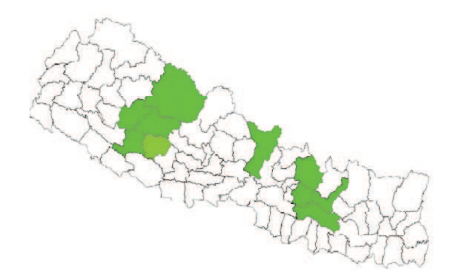

Figure 2: Districts affected in 1997

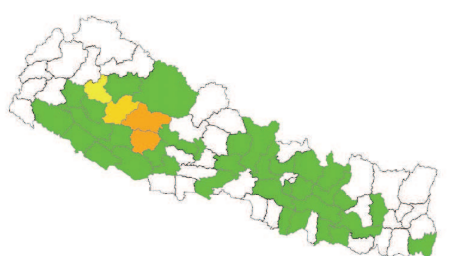

Figure 4: Districts affected in 1999

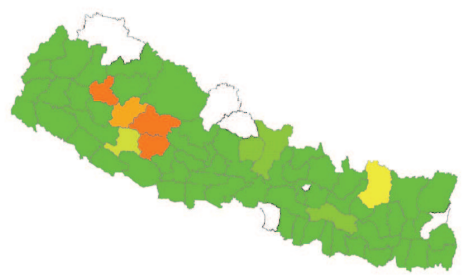

Figure 6: Districts affected in 2001
Note: The intensity of the violence scale goes from light to darker shades of green, then to yellow, orange, and red, the last being the most violent.

cumulative violence they experienced: "Nearby" districts suffered violence earlier and more severely than did "far away" districts.

This observation is confirmed in Figures 1 through 6. Figure 1 highlights the districts in which the war began. Figure 2 shows districts affected a year later (1997). Similarly, Figures 3-6 illustrate the spatial spread of the war from 1998 to 2001. In addition to the geographic spread of war, the figures reveal the temporal increase in violence. The darker the shading (light green to red), the more intense the violence. Descriptively, the figures show that war spread geographically and grew more ferocious over time.

\section{Methodology and results}

Before discussing the full analytic model, a preliminary analysis not accounting for the spatial nature of war and without the correlation between the two stages is carried out. This is done to test whether in the absence of factoring in the spatial nature of the war, the results are comparable to other studies of war. Table 3 suggests that they are: The socioeconomic conditions of an area are important for war onset and escalation. Columns I-III of Table 3 pertain to war onset in an area, whereas columns IV-VI reports on violence escalation measures.

As may be seen in column I of Table 3, poverty, literacy rate, forest density, and ethnicity are statistically significant in determining the timing of the onset of violence. A negative sign indicates an earlier onset of violence (nearer to 1996). More densely forested areas and areas with higher concentration of "militant" ethnic groups were drawn into violence earlier as well. In contrast, poorer areas and areas with low literacy rates experienced a later onset of violence. Column II replaces poverty with aggregate rainfall and road density with elevation. The findings reported in columns I and II appear to broadly conform to the findings of other studies in that forest density, elevation, ethnicity, poverty, and literacy are associated-one way or another-with an upsurge in violence.

Column III, however, takes distance into account. With the inclusion of this indicator, the other conditions no longer are significant, statistically speaking, except for "ethnicity" (and then with the opposite sign). Further, including distance in the analysis statistically fits data somewhat better. Similar observations apply to models IV, V, and VI of Table 3.

Another model is developed to more completely capture the two dimensions of war, a contagion stage whereby war spreads to nearby areas (onset), and an intensity stage whereby violence in any given affected district escalates (escalation). Onset is modeled using a Poisson distribution. The idea is that once war starts in a district the time elapsed between this onset and the year by which it spreads to another district can be thought of as waiting time before the change is noticed. A Poisson distribution can approximate this waiting time, which is a discrete number ranging from 0 (if an area was affected in 1996) to 6 (if an area was affected in 2001). If districts did not experience violence by 2001 , however, there is still a chance that those districts will have been affected after 2001. Hence, the data is truncated at 2001. The model takes this truncation into account as well.

The escalation stage is modeled with an OLS equation. This stage is correlated with the onset stage to allow unobserved heterogeneity in contagion and intensity to be interrelated. For example, if poverty affects how quickly a district gets drawn into war, then it is possible that poverty also influences the intensity of violence in the district. The correlation therefore helps us to understand the relationship, if any, between the two stages. I then use the Maximum Likelihood technique to estimate the importance of geography, socioeconomic conditions, and proximity in war onset 
(C) www.epsjournal.org.uk - Vol. 8, No. 2 (2013)

Table 3: Preliminary analysis

\begin{tabular}{|c|c|c|c|c|c|c|}
\hline \multirow[t]{2}{*}{ Variable } & \multicolumn{3}{|l|}{ Onset (a) } & \multicolumn{3}{|c|}{ Escalation (b) } \\
\hline & $I$ & II & $I I I$ & $I V$ & $V$ & $V I$ \\
\hline Distance & - & - & $\begin{array}{l}3.157 * * * \\
(0.575)\end{array}$ & - & - & $\begin{array}{l}13.55^{* * *} \\
(2.375)\end{array}$ \\
\hline Distance squared & - & - & $\begin{array}{l}1.061 * * * \\
(0.246)\end{array}$ & - & - & $\begin{array}{l}5.302 * * * \\
(1.160)\end{array}$ \\
\hline Poverty & $\begin{array}{l}1.447 * * \\
(0.581)\end{array}$ & - & $\begin{array}{l}-0.784 \\
(0.690)\end{array}$ & $\begin{array}{l}2.299 \\
(6.014)\end{array}$ & - & $\begin{array}{l}5.451 \\
(5.047)\end{array}$ \\
\hline Literacy rate & $\begin{array}{l}3.108^{* * *} \\
(0.712)\end{array}$ & $\begin{array}{l}2.823 * * * \\
(0.884)\end{array}$ & $\begin{array}{l}-1.054 \\
(1.044)\end{array}$ & $\begin{array}{l}-10.693 \\
(6.682)\end{array}$ & $\begin{array}{l}-12.728^{* *} \\
(6.324)\end{array}$ & $\begin{array}{l}-0.401 \\
(6.347)\end{array}$ \\
\hline Population density & $\begin{array}{l}-0.037 \\
(0.076)\end{array}$ & $\begin{array}{l}-0.028 \\
(0.030)\end{array}$ & $\begin{array}{l}0.021 \\
(0.084)\end{array}$ & $\begin{array}{l}-0.314 \\
(0.524)\end{array}$ & $\begin{array}{l}-0.044 \\
(0.539)\end{array}$ & $\begin{array}{l}-0.430 \\
(0.444)\end{array}$ \\
\hline Forest density & $\begin{array}{l}-1.077 * * \\
(0.450)\end{array}$ & $\begin{array}{l}-0.424 \\
(0.353)\end{array}$ & $\begin{array}{l}-0.165 \\
(0.481)\end{array}$ & $\begin{array}{l}5.086^{*} \\
(2.811)\end{array}$ & $\begin{array}{l}5.828 * * \\
(2.497)\end{array}$ & $\begin{array}{l}2.403 \\
(2.488)\end{array}$ \\
\hline Road density & $\begin{array}{l}0.276 \\
(0.991)\end{array}$ & - & $\begin{array}{l}0.821 \\
(1.030)\end{array}$ & $\begin{array}{l}6.077 \\
(6.789)\end{array}$ & - & $\begin{array}{l}3.483 \\
(5.571)\end{array}$ \\
\hline Communist stronghold & $\begin{array}{l}0.182 \\
(0.537)\end{array}$ & $\begin{array}{l}0.371 \\
(0.543)\end{array}$ & $\begin{array}{l}-0.579 \\
(0.520)\end{array}$ & $\begin{array}{l}-5.007 \\
(3.447)\end{array}$ & $\begin{array}{l}-4.630 \\
(3.453)\end{array}$ & $\begin{array}{l}-0.608 \\
(2.895)\end{array}$ \\
\hline Ethnicity & $\begin{array}{l}-0.901 * * \\
(0.416)\end{array}$ & $\begin{array}{l}-0.646 \\
(0.395)\end{array}$ & $\begin{array}{l}0.901^{*} \\
(0.508)\end{array}$ & $\begin{array}{l}2.245 \\
(2.854)\end{array}$ & $\begin{array}{l}2.272 \\
(2.505)\end{array}$ & $\begin{array}{l}-3.239 \\
(2.714)\end{array}$ \\
\hline Rainfall & & $\begin{array}{l}0.058 \\
(0.118)\end{array}$ & & & $\begin{array}{l}0.446 \\
(0.865)\end{array}$ & \\
\hline Elevation & & $\begin{array}{l}0.0014^{*} \\
(0.00084)\end{array}$ & & & $\begin{array}{l}0.0107 \\
(0.007)\end{array}$ & \\
\hline Observations & 73 & 73 & 73 & 73 & 73 & 73 \\
\hline Log-Likelihood (R-sq) & -137.906 & -140.033 & -116.558 & 0.224 & 0.254 & 0.504 \\
\hline
\end{tabular}

Notes: (a) Onset: The dependent variable is time elapsed (in years) since the war started and since the first violence incidence in a district. It is implemented using a Poisson distribution. (b) Escalation: The dependent variable is yearly violence intensity. The two stages are analyzed separately. ${ }^{*}, * *$, and $* * *$ denote statistical significance at the 10,5 , and 1 percent levels, respectively.

(contagion, or geographic spread) and escalation (intensity of violence over time).

Table 4 presents the main results of the estimation. Columns I, II, III and columns IV, V, VI pertain to onset and escalation, respectively. Column I reports the full model, column II tests whether the local conditions are jointly significant in explaining war spread, and column III tests the explanatory power of distance alone.

The effect of distance is substantial in all cases. A district's socioeconomic conditions (poverty, literacy, etc.) do not statistically influence the onset or spread of violence (column I), and its strategic importance (stronghold, ethnicity) is only marginally significant. The negative sign on the communist stronghold variable indicates that the greater the share of votes received by the Communist Party, the
Table 4: Results

\begin{tabular}{|c|c|c|c|c|c|c|}
\hline \multirow[t]{2}{*}{ Variable } & \multicolumn{3}{|l|}{ Onset (a) } & \multicolumn{3}{|c|}{ Escalation (b) } \\
\hline & $I$ & II & $I I I$ & $I V$ & $V$ & $V I$ \\
\hline Distance & $\begin{array}{l}3.542 * * * \\
(0.642)\end{array}$ & - & $\begin{array}{l}2.733 * * * \\
(0.598)\end{array}$ & - & - & - \\
\hline Distance squared & $\begin{array}{l}-1.231 * * * \\
(0.275)\end{array}$ & - & $\begin{array}{l}-0.934 * * * \\
(0.268)\end{array}$ & - & - & - \\
\hline Poverty & $\begin{array}{l}-0.949 \\
(0.949)\end{array}$ & $\begin{array}{l}0.954 \\
(1.019)\end{array}$ & - & $\begin{array}{l}11.686 \\
(15.785)\end{array}$ & $\begin{array}{l}7.841 \\
(16.413)\end{array}$ & $\begin{array}{l}8.931 \\
(15.911)\end{array}$ \\
\hline Literacy rate & $\begin{array}{l}-1.113 \\
(1.273)\end{array}$ & $\begin{array}{l}2.789 * * \\
(1.117)\end{array}$ & - & $\begin{array}{l}-5.516 \\
(17.268)\end{array}$ & $\begin{array}{l}-4.137 \\
(19.482)\end{array}$ & $\begin{array}{l}-4.367 \\
(17.192)\end{array}$ \\
\hline Population density & $\begin{array}{l}0.019 \\
(0.087)\end{array}$ & $\begin{array}{l}-0.059 \\
(0.083)\end{array}$ & - & $\begin{array}{l}-1.576 \\
(1.272)\end{array}$ & $\begin{array}{l}-1.249 \\
(1.314)\end{array}$ & $\begin{array}{l}-1.176 \\
(1.260)\end{array}$ \\
\hline Forest density & $\begin{array}{l}-0.277 \\
(0.500)\end{array}$ & $\begin{array}{l}-0.991 \\
(0.514)\end{array}$ & - & $\begin{array}{l}2.104 \\
(7.394)\end{array}$ & $\begin{array}{l}4.098 \\
(8.106)\end{array}$ & $\begin{array}{l}5.101 \\
(7.244)\end{array}$ \\
\hline Road density & $\begin{array}{l}0.927 \\
(1.071)\end{array}$ & $\begin{array}{l}0.304 \\
(1.077)\end{array}$ & - & $\begin{array}{l}15.380 \\
(16.520)\end{array}$ & $\begin{array}{l}7.838 \\
(17.077)\end{array}$ & $\begin{array}{l}7.906 \\
(16.336)\end{array}$ \\
\hline Communist stronghold & $\begin{array}{l}-0.966^{*} \\
(0.514)\end{array}$ & $\begin{array}{l}0.455 \\
(0.611)\end{array}$ & - & $\begin{array}{l}-13.310 \\
(8.602)\end{array}$ & $\begin{array}{l}-11.126 \\
(8.878)\end{array}$ & $\begin{array}{l}-12.029 \\
(8.512)\end{array}$ \\
\hline Ethnicity & $\begin{array}{l}1.119^{* *} \\
(0.527)\end{array}$ & $\begin{array}{l}-0.907^{*} \\
(0.484)\end{array}$ & - & $\begin{array}{l}0.735 \\
(7.284)\end{array}$ & $\begin{array}{l}0.881 \\
(7.928)\end{array}$ & $\begin{array}{l}1.370 \\
(7.510)\end{array}$ \\
\hline Duration & - & - & - & $\begin{array}{l}6.164 * * * \\
(2.133)\end{array}$ & $\begin{array}{l}6.080 * * * \\
(2.354)\end{array}$ & $\begin{array}{l}6.097 * * * \\
(2.128)\end{array}$ \\
\hline Duration squared & - & - & - & $\begin{array}{l}-0.708^{* *} \\
(0.342)\end{array}$ & $\begin{array}{l}-0.709 * * \\
(0.344)\end{array}$ & $\begin{array}{l}-0.713 * * \\
(0.342)\end{array}$ \\
\hline
\end{tabular}

Notes: (a) Onset: The dependent variable is time elapsed (in years) since the war started and the first violence incidence in a district. It is implemented using a Poisson distribution. (b) Escalation: The dependent variable is yearly violence intensity. Time fixed effects are included in all the analysis. *, **, and *** denote statistical significance at the 10,5 , and 1 percent levels, respectively.

quicker the onset of violence. This conforms to ideas posited by other scholars who argue that the presence of communist supporters in a district aided the Maoist struggle. As such, areas with a higher concentration of Communist Party supporters were engulfed by war earlier on in the insurgency. In contrast, the coefficient for ethnicity is positive: A higher concentration of an ethnic group thought to be militant in nature delayed the onset of violence in those districts. This result does not seem to support researchers' claim that these groups provided military and tactical support for the Maoists, at least not in their home districts.

None of the other conditions are statistically significant and this result is consistent across the different model specifications. Indeed, unlike distance, a statistical 
hypothesis that the local drivers of war are jointly insignificant cannot be rejected at the 95 percent level of confidence. Similarly, none of the socioeconomic conditions are significant in explaining war escalation either (models IV, V, and VI). The most influential variable in explaining war intensity is simply its duration. In both cases - distance and duration - the statistically significant negative sign on the squared terms says that the further away is a district in space and time when violence is first experienced, the better. Qualitatively, this is not startling news, but the novelty of this article lies in the quantitative demonstration.

As mentioned, annual rainfall may be a better indicator of variation in income than is the share of the population living below the national poverty line. Hence, I also analyzed the main model specification with annual rainfall data instead of with the poverty measure. Similarly, I used elevation instead of road density. In either case, the main result does not change.

Since poverty, lower literacy rates, and rugged terrain have long been thought to affect the spread the war and its duration, it may seem puzzling that none of these variables are statistically significant, at least not for Nepal for the years 1996 to 2001 . Poverty and lower literacy rates, for example, might increase the incidence of violence by lowering the opportunity cost of participating in a revolt. But this assumes that the poor and illiterate join a rebel army voluntarily, and there are examples that point to the contrary case, for instance Ugandan children mass-abducted in the 1990s by LRA insurgents. But even putting those sorts of cases aside, one pair of scholars also finds the relationship between poverty and war-violence to be spurious, just as for the case of Nepal reported here. Similarly, regional differences in literacy rates can challenge the view that lower levels of literacy are linked to the outbreak of war. For example, although African countries have low levels of schooling and high levels of violence, countries such as Lebanon, Cyprus, Yugoslavia, and Georgia had high schooling rates at the time of war. Thus, it need not surprise to find that the conflict in Nepal did not readily spread through areas of high poverty and low literacy. Other enabling and disabling mechanisms may be at work. ${ }^{9}$

As to rugged terrain, this is thought to create a geographical barrier between rebels and government. Defense forests, and the lack of roads, may then provide suitable places for rebels to hide or otherwise to use to their advantage. But at least during the initial phase of the Nepali war, Maoists sought refuge in neighboring India, not in the hinterlands of Nepal. Likewise, meetings and training were carried out in India. In a word, for the Maoist rebels more important than the country's rugged terrain or its dense forests - more important than its topography-were its Communist Party supporters and Nepal's porous international border with India. Viewed this way, the relative unimportance of geography reported in this article does not appear surprising. ${ }^{10}$

\section{Conclusion}

The importance of proximity to explain the spread of war has long been recognized. This study furthers this knowledge by formalizing war spread and escalation of war intensity within a country. The model helps us understand key drivers of war spread and separately from the mechanisms that make violence escalate over time. For Nepal, for 1996 to 2001, distance from any war-affected area is the most significant predictor for the spread of war. None of the drivers previously thought to breed insurgent activity are statistically significant. The results are insensitive to alternative measures of poverty, road connectivity, and relative location.

Besides helping us to understand within-country variation in war attributes, in pointing to mere distance as an underlying transmission mechanism of the spread of war, one policy implication is simply that hot-spot areas ought to be targeted for intervention at the earliest possible stage: Do not let war fester. This is so because war, like a contagious disease, first spreads to nearby areas before it becomes more ferocious over time. Further, this study highlights that to understand the heterogeneity of war within a country, one must focus on local-level politics while taking the possibly transnational nature of civil war into account. As richer data at subnational levels are increasingly becoming available, our approach to understanding the nature of war needs to incorporate administrative-level (e.g., district) data and adopt statistical methods to exploit the variation in the more detailed data.

Notes

Shikha Silwal is an Assistant Professor of Economics at Washington and Lee University, Lexington, VA, USA. She may be reached at <silwals@wlu.edu>.

1. Diffusion and contagion are two different mechanisms by which war spreads in space. If war spreads as a result of a gain in knowledge in war-related tactics, it is said to have diffused. In contrast, if war spreads due to a physical movement of armed activities from one to another war-affected area, it spreads via contagion. Since it is a matter of argument as to which of these mechanisms is at play, I do not distinguish between the two mechanisms in this article and simply talk about the spatial spread of war in general.

2. As per Gleditsch (2002), if fighting results in more than 1,000 deaths in a given year, it is categorized as war.

3. District patterns: Bohara, et al. (2006). A district is an administrative unit. There are 75 districts in Nepal. The others: Murshed and Gates (2005); Do and Iyer (2012)

4. Poverty and grievance: Collier and Hoeffler (2000). Rainfall: Miguel, et al. (2004). 
(C) www.epsjournal.org.uk - Vol. 8, No. 2 (2013)

5. Opportunity for rebellion: Fearon and Laitin (2003).

6. Spatial spillover studies: For example, Buhaug and Gleditsch (2008); Gleditsch (2002); Hill and Rothchild (1986); McColl (1967); Most and Starr (1980); Murdoch and Sandler (2002); Raleigh, et al. (2010); Starr (2003).

7. Some scholars: McColl (1967); Raleigh and Hegre (2009).

8. These ethnic groups are the Magar, Rai, Tamang, Limbu, and Gurung. They formed the majority of Nepalis who served with the British. On Magars specifically, see, e.g., Thapa and Sijapati (2004).

9. Poverty and war-violence: Djankov and Reynal-Querol (2010). Schooling: Sambanis (2009).

10. On mountain people and war, also see Pickering (2011). Not surprising: Along similar lines, Raleigh and Hegre (2009) find that war in Central African countries was not primarily located in difficult-to-access hinterland districts.

\section{References}

Bohara, A.K., N. J. Mitchell, and M. Nepal. 2006. "Opportunity, Democracy, and the Exchange of Political Violence: A Subnational Analysis of Conflict in Nepal." Journal of Conflict Resolution. Vol. 50, No. 1, pp. 108-128.

Buhaug, H. and K.S. Gleditsch. 2008. "Contagion or Confusion? Why Conflicts Cluster in Space.” International Studies Quarterly. Vol. 52, No. 2, pp. 215-233.

Collier, P. and A. Hoeffler. 2000. "Greed and Grievance in Civil War." Working Paper 2355. Washington, D.C.: World Bank.

Djankov, S. and M. Reynal-Querol. 2010. "Poverty and Civil Wars: Revisiting the Evidence." Review of Economics and Statistics. Vol. 92, No. 4, pp. 1035-1041.

Do, Q.T. and L. Iyer. 2010. "Geography, Poverty and Conflict in Nepal." Journal of Peace Research. Vol. 47, No. 6, pp. 735-748.

Fearon, J and D. Laitin. 2003. "Ethnicity, Insurgency, and Civil War." American Political Science Review. Vol. 97, No. 1, pp. 75-90.

Gleditsch, K.S. 2002. All International Politics is Local: The Diffusion of Conflict Integration, and Democratization. Ann Arbor, MI: University of Michigan Press.

Hill, S. and D. Rothchild. 1986. "The Contagion of Political Conflict in Africa and the World.” Journal of Conflict Resolution. Vol. 30, No. 4, pp. 716-735.

McColl, R. 1967. "A Political Geography of Revolution: China, Vietnam and Thailand." Journal of Conflict Resolution. Vol. 11, No. 2, pp. 153-167.

Miguel, E., S. Satyanath, and E. Sergenti. 2004. "Economic Shocks and Civil Conflict: An Instrumental Variables Approach." Journal of Political Economy,.
Vol. 112, No. 4, pp. 725-753.

Most, B.A. and H. Starr. 1980. "Diffusion, Reinforcement, Geopolitics, and the Spread of War." American Political Science Review. Vol. 74, No. 4, pp. 932-946.

Murdoch, J.C. and T. Sandler. 2002. "Economic Growth, Civil Wars, and Spatial Spillovers." Journal of Conflict Resolution. Vol. 46, pp. 91-110.

Murshed, S.M. and S. Gates. 2005. "Spatial-Horizontal Inequality and the Maoist Insurgency in Nepal." Review of Development Economics. Vol. 9, No. 1, pp 121-134

Nepal Living Standards Survey (I and II). Kathmandu: Bureau of Statistics, National Planning Commission Secretariat, Government of Nepal.

Pickering, S. 2011. "Determinism in the Mountains: The Ongoing Belief in the Bellicosity of 'Mountain People'.” The Economics of Peace and Security Journal. Vol. 6, No. 2, pp. 21-25.

Population Census. Kathmandu: Central Bureau of Statistics, National Planning Commission Secretariat, Government of Nepal 1980, 1990, and 2000.

Raleigh, C. and H. Hegre. 2009. "Population Size, Concentration, and Civil War: A Geographically Disaggregated Analysis.” Political Geography. Vol. 28, No. 4, pp. 224-238.

Raleigh, C., D.W. Frank, and W. J. O’Loughlin. 2010. “A Review and Assessment of Spatial Analysis of Conflict: The Geography of War." The International Studies Encyclopedia. Vol. 10, pp. 6534-6553.

Road Statistics. Kathmandu: Ministry of Physical Planning and Works,1989-2008.

Sambanis, N. 2009. "Using Case Studies to Expand Economic Models of Civil War." Perspectives on Politics. Vol. 2, No. 2, pp. 259-279.

Small Area Estimation of Poverty, Caloric Intake and Malnutrition Nepal. Kathmandu: Bureau of Statistics. (Joint publication with the World Bank and the United Nations World Food Programme). National Planning Commission Secretariat, Government of Nepal.

Starr, H. 2003. "The Power of Place and the Future of Spatial Analysis in the Study of Conflict." Conflict Management and Peace Science. Vol. 20, No. 1, pp. 1-20.

Statistical Yearbook of Nepal. Kathmandu: Bureau of Statistics, National Planning Commission Secretariat, Government of Nepal.

Thapa, D. and Sijapati B. 2004. A Kingdom Under Siege. Kathmandu, Nepal: Printhouse. 